\title{
The curious case of a woman with two BRCA1 mutations in trans
}

\author{
Rodney J Scott*, Michelle Wong-Brown, Mary McPhillips, Susan Dooley, Allan Spigelman, Margaret Gleeson, \\ Cliff Meldrum
}

From Annual Conference on Hereditary Cancers 2014

Szczecin, Poland. 25-26 September 2014

Since the identification of $B R C A 1$ twenty years ago there has not been a single unequivocal case of anyone (even in populations where there is a high frequency of founder mutations) harboring two BRCA1 mutations in trans, suggesting that this is embryonically lethal. These findings have been substantiated by animal models where no viable offspring $B R C A$ null mice have been generated by crossing heterozygote carriers. It is known that Brca1 mice can be partially rescued by $T p 53$ mutations, but they do not survive well. Recently one patient has been reported with a nonsense mutation on one BRCA1 allele and a missense on the other. The patient in this study suffered from malignancy, intellectual disability and a number of other symptoms. The missense variant has not been extensively verified and as such cannot be verified as pathogenic at this time.

Here we report a woman, diagnosed with breast cancer during her fourth decade of life, who has been shown to harbour one nonsense mutation and a splice site mutation. Both changes results in the loss of wild-type BRCA1. The question raised by this finding is: How come this woman is alive and outside of her initial presentation is currently healthy? An in depth molecular analysis was performed which revealed the complexity of BRCA1 expression and how this could only be achieved by close examination of other family members. The outcome of the study represents the most likely explanation for this extraordinary case.

\section{Consent to publish}

Written informed consent was obtained from the patient for publication of this abstract and any accompanying images.

\footnotetext{
* Correspondence: rodney.scott@newcastle.edu.au

Discipline of Medical Genetics, Faculty of Health, University of Newcastle and Hunter Medical Research Institute, Newcastle, NSW, Australia
}

Published: 26 November 2015

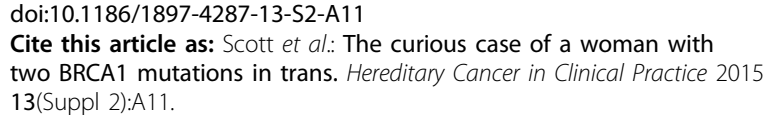

Submit your next manuscript to BioMed Central and take full advantage of:

- Convenient online submission

- Thorough peer review

- No space constraints or color figure charges

- Immediate publication on acceptance

- Inclusion in PubMed, CAS, Scopus and Google Scholar

- Research which is freely available for redistribution
() Biomed Central

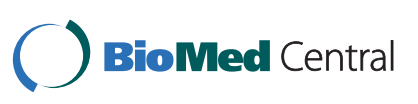

